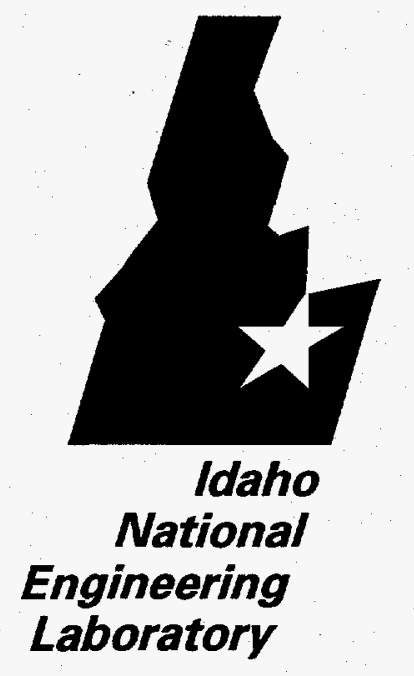

INEL-95/0269

June 1995

Environment, Safety, Health, and Quality Plan for the TRU-Contaminated Arid Soils Project of the Landfill Stabilization Focus Area Program

L. R. Watson

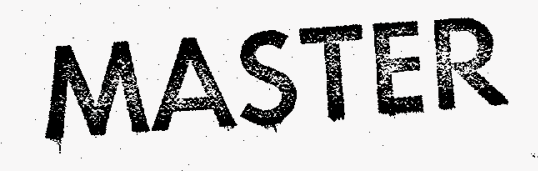

三Llockheed

Idaho Technologles Company 


\section{DISCLAIMER}

This report was prepared as an account of work sponsored by an agency of the United States Government. Neither the United States Government nor any agency thereof, nor any of their employees, makes any warranty, express or implied, or assumes any legal liability or responsibility for the accuracy, completeness, or usefulness of any information, apparatus, product or process disclosed, or represents that its use would not infringe privately owned rights. References herein to any specitic commercial product, process, or service by trade name, trademark, manufacturer, or otherwise, does not necessarily constitute or imply its endorsement, recommendation, or favoring by the United States Government or any agency thereof. The views and opinions of authors expressed herein do not necessarily state or reflect those of the United States Government or any agency thereof. 


\section{DISCLAMERR}

Portions of this document may be illegible in electronic image products. Images are produced from the best available original document. 
INEL-95/0269

\title{
Environment, Safety, Health, and Quality Plan for the TRU-Contaminated Arid Soils Project of the Landfill Stabilization Focus Area Program
}

L. R. Watson

Published June 1995

\author{
Idaho National Engineering Laboratory \\ Environmental Restoration Technologies Department \\ Lockheed Martin Idaho Technologies \\ Idaho Falls, Idaho $\mathbf{8 3 4 1 5}$
}

Prepared for the

U.S. Department of Energy

Assistant Secretary for Environmental Management

Office of Technology Development

Under DOE Idaho Operations Office

Contract DE-AC07-94ID13223

DISTRIBUTION OF THS DOCW.WEN IS UMLMTEIN 
Environment, Safety, Health, and Quality Plan for the TRU-Contaminated Arid Soils Project of the Landfill Stabilization Focus Area Program

INEL-95/0269

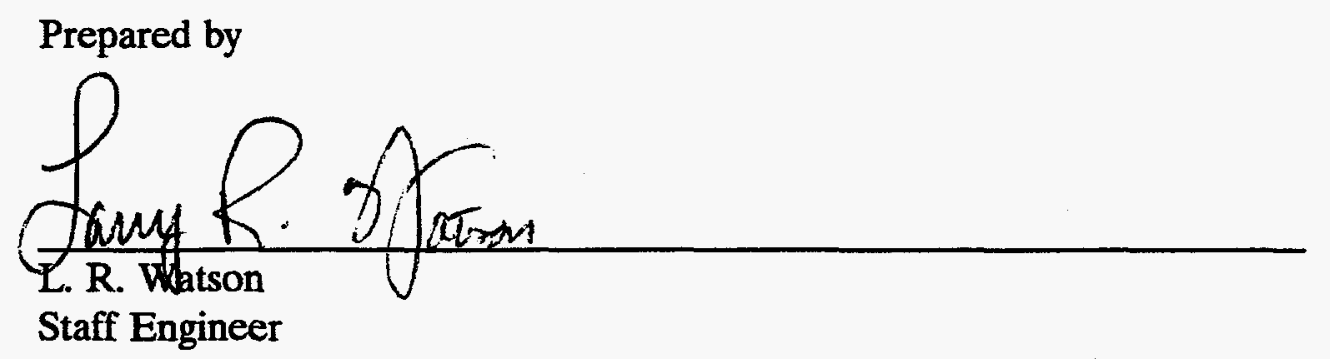

$\frac{\text { June tl, } 1995}{\text { Date }}$

Reviewed by

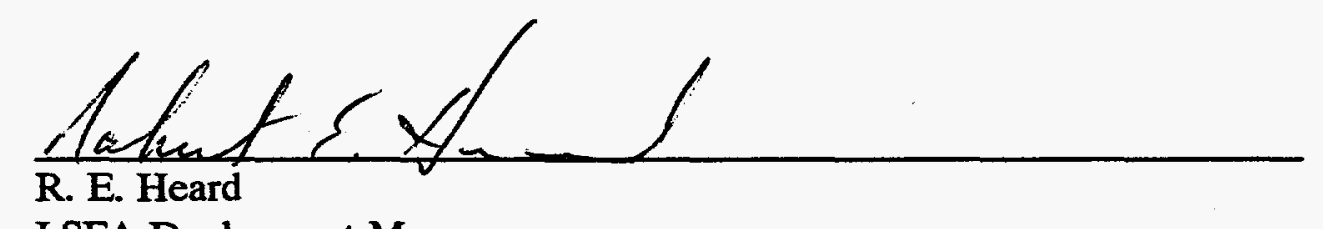

$$
\frac{6 / 2 / 95}{\text { Date }}
$$

LSFA Deployment Manager

Approved by
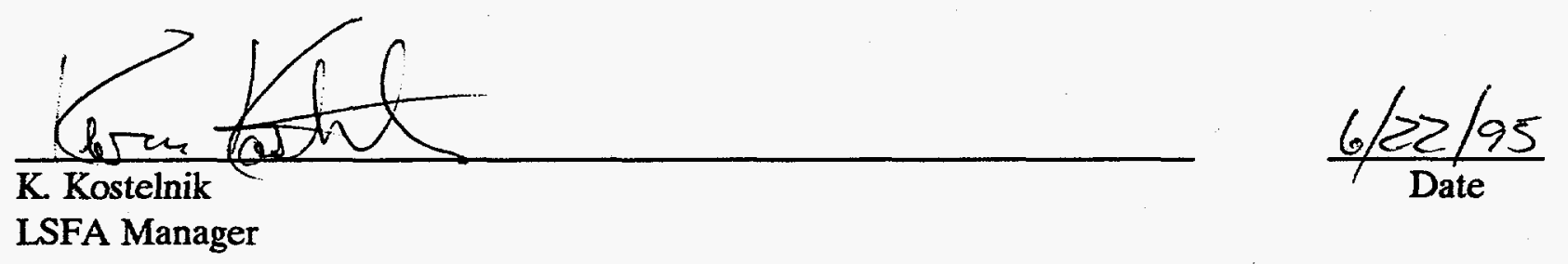



\section{ABSTRACT}

The Landfill Stabilization Focus Area (LSFA) is a program funded by the U.S. Department of Energy Office of Technology Development. LSFA supports the applied research, development, demonstration, testing, and evaluation of a suite of advanced technologies that together form a comprehensive remediation system for the effective and efficient remediation of buried waste.

The TRU-Contaminated Arid Soils project is being conducted under the auspices of the LSFA Program. This document describes the Environment, Safety, Health, and Quality requirements for conducting LSFA/Arid Soils activities at the Idaho National Engineering Laboratory. Topics discussed in this report, as they apply to LSFA/Arid Soils operations, include Federal, State of Idaho, and Environmental Protection Agency regulations, Health and Safety Plans, Quality Program, Data Quality Objectives, and training and job hazard analysis. Finally, a discussion is given on CERCLA criteria and system and performance audits as they apply to the LSFA Program. 


\section{SUMMARY}

The major goal of this report is to confirm that the Landfill Stabilization Focus Area (LSFA) Program's commitment for ensuring that operations at the Idaho National Engineering Laboratory (INEL) and offsite are conducted in conformance with all applicable environmental regulations. As specified in this report, protocols are in place to conduct LSFA operations under all environmental guidelines.

The National Environmental Policy Act of 1969 declared a national policy of greater environmental awareness by requiring a systematic, interdisciplinary review of any proposed Federal action. This review is designed to assess the environmental impacts of the action, propose and assess any alternatives to the action, and state any irreversible and irretrievable commitments of resources should the proposed action be implemented. It also requires consultation with and comments from any Federal, state, and local agencies with jurisdiction or interest in the proposed action, and it provides an opportunity for public input.

All LSFA field demonstrations at the INEL will be performed at the Cold Test Pit, North Boulevard Robotics Complex (NBRC), or the Box Canyon Site. Although LSFA has received approval for creation and general use of the site, each project that will field test a technology at the Cold Test Pit must undergo separate NEPA review and approval. Documentation regarding these decisions will be located in the LSFA program files.

Solid wastes generated from LSFA operations are managed in accordance with the Company Procedures Manual, Section 8.12. LSFA projects performed at the INEL are covered by the Health and Safety Plan as addressed in the Company Safety Manual Section 1. Projects performed at the non-INEL facilities must follow an acceptable health and safety plan for the location where the work is performed. Hazard Communication requirements are a result of Occupational Safety and Health Administration (OSHA) regulations regarding the use of hazardous chemicals. MSDSs will be located in the administration trailer, near the Cold Test Pit or the control area of the NBRC. A job hazard analysis will he performed and will entail a review of the chemical, biological, and physical hazards of the operation as well as the Industrial Hygienist's (IH's) and Safety Engineer's evaluations or risk assessments of the hazards.

All work performed at the INEL must be reviewed and approved by a Facility Health and Safety Representative, as required, and documented in Safe Work Permits. All work shall be performed in compliance with all of the health and safety requirements for the LSFA project as identified in both generic and project-specific training requirements to ensure the safety of project personnel. Safety walkdowns of the Cold Test Pit and NBRC areas shall be conducted by the LSFA safety engineers. Safety discrepancies and concerns shall be reported to the LSFA Deployment Project Manager. Corrections will be funded and completed by LSFA or by the Field Test Principal Investigator, depending on the nature of the identified problem.

The Quality Assurance Program shall be used for LSFA field tests per DOE Order 5700.6C and DOE-ID Order 5700.6E. The Company Quality Manual is the Quality Assurance Program discussed in this report. Data Quality Objectives, qualitative and quantitative statements that 
specify the targeted quality required of data gathered during testing, will be used for LSFA operations. Performance audits are conducted to quantitatively evaluate the outputs of a measurement system. System audits are conducted to qualitatively evaluate the operational details of a quality assurance (QA) program. These audits will be conducted internally by the LSFA Deployment QA support member.

LSFA has included the CERCLA criteria for evaluating the buried waste remediation technologies it is funding. These criteria are used because end products of LSFA are intended for use by Environmental Restoration/Waste Management (ER/WM), who will be required to comply with CERCLA. 


\section{CONTENTS}

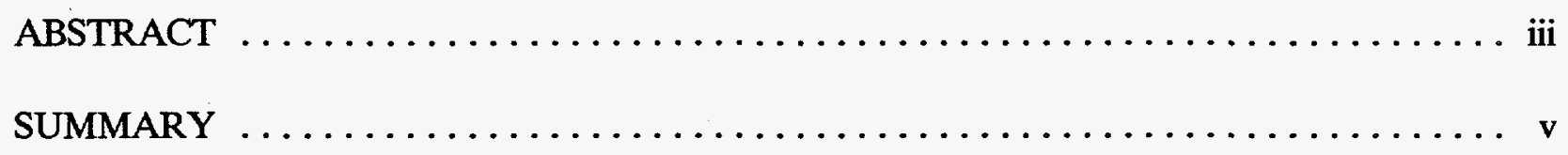

ACKNOWLEDGMENTS $\ldots \ldots \ldots \ldots \ldots \ldots \ldots \ldots \ldots \ldots \ldots \ldots \ldots \ldots \ldots \ldots \ldots$ viii

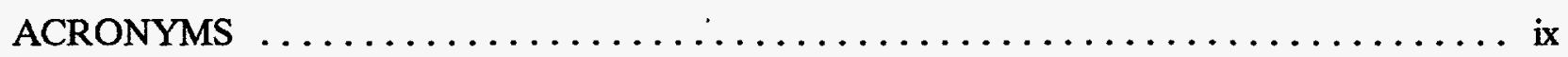

1. ENVIRONMENTAL ISSUES $\ldots \ldots \ldots \ldots \ldots \ldots \ldots \ldots \ldots \ldots \ldots \ldots \ldots \ldots \ldots \ldots \ldots \ldots \ldots$

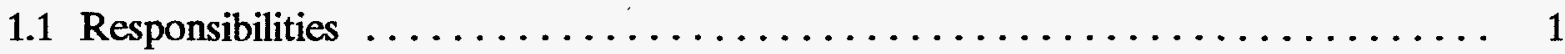

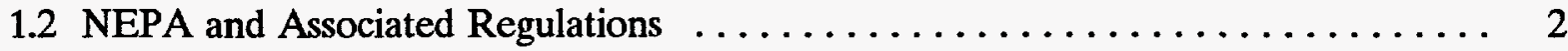

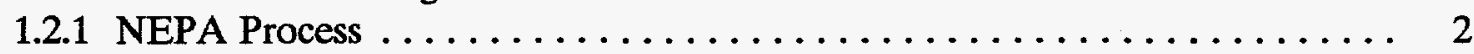

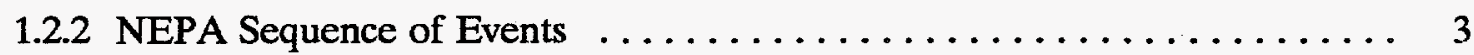

1.3 Waste Minimization and Pollution Prevention $\ldots \ldots \ldots \ldots \ldots \ldots \ldots \ldots . . \ldots \ldots$

1.4 INEL Field Demonstrations . . . . . . . . . . . . . . . . . . . . . . 5

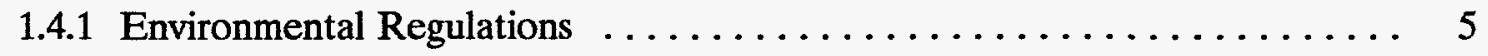

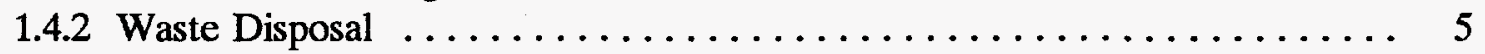

2. HEALTH AND SAFETY ISSUES $\ldots \ldots \ldots \ldots \ldots \ldots \ldots \ldots \ldots \ldots \ldots \ldots \ldots \ldots$

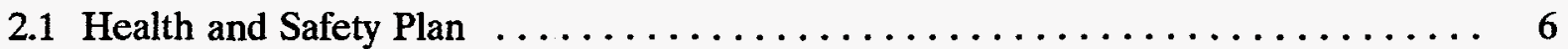

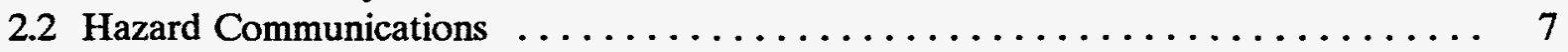

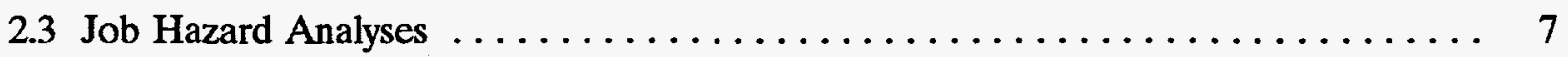

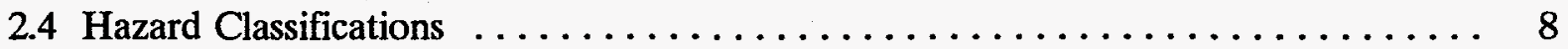

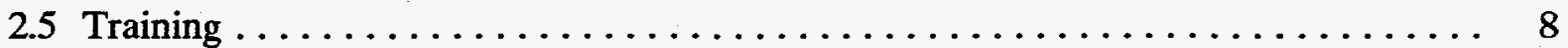

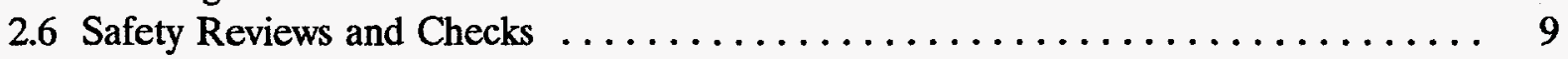

2.7 Safe Work Permits ............................... 11

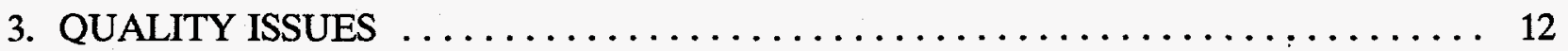

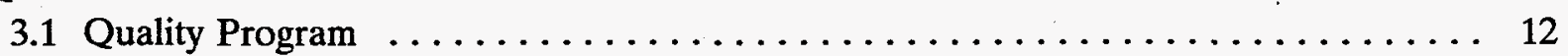

3.2 Data Quality Objectives .............................. 14

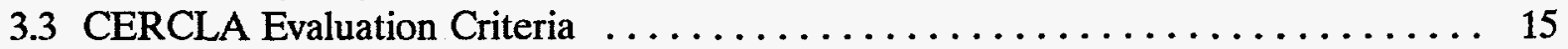

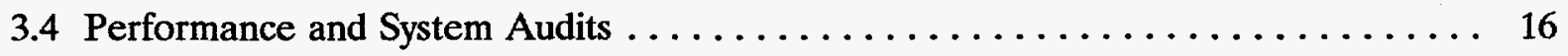

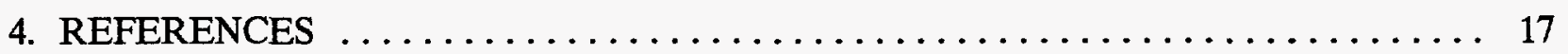

\section{TABLES}

1. Health and Safety Compliance Checklist. ....................... 6

2. LSFA Field Test Monitoring Checklist. . . . . . . . . . . . . . 


\section{ACKNOWLEDGMENTS}

The author thanks the following Lockheed Martin Idaho Technologies personnel for contributing to this report: Lewis Rounds, Jim Graham, John Morrison, and Doug Stacey. 


\section{ACRONYMS}

ALARA As Low As Reasonably Achievable

ANSI American National Standards Institute

ARARs Applicable or Relevant and Appropriate Requirements

BLM Bureau of Land Management

CERCLA Comprehensive Environmental Response, Compensation, and Liability Act

CFA Central Facilities Area

CFR Code of Federal Regulations

CTP Cold Test Pit

CX Categorical Exclusion

DOPs Detailed Operating Procedures

DQOs Data Quality Objectives

EC Environmental Checklist

EPD Environmental Protection Department

ER\&A Environmental Research and Application

ER/WM Environmental Restoration/Waste Management

ESH\&Q Environment, Safety, Health, and Quality

F\&M Facilities and Maintenance

HP Health Physics

IH Industrial Hygienist

INEL Idaho National Engineering Laboratory

LDR Land Disposal Restriction

LSFA Landfill Stabilization Focus Area 
LMIT Lockheed Martin Idaho Technologies

MSDS Material Safety Data Sheet

M\&TE Measurement and Test Equipment

NBRC North Boulevard Robotics Complex

NEPA National Environmental Policy Act

O\&M Operation and Maintenance

OSHA Occupational Safety and Health Administration

PI Principal Investigator

PM Project Manager

PPE Personnel Protective Equipment

TWAs Process Waste Assessments

QA Quality Assurance

QAP Quality Assurance Plan

RCRA Resource Conservation and Recovery Act

RI/FS Remedial Investigation/Feasibility Study

SARA Superfund Amendments and Reauthorization Act of 1986

SWPPP Stormwater Pollution Prevention Plan

T\&E Threatened and Endangered

TRU Transuranic Waste

TIPs Technical Task Plans

$\mathbf{x}$ 


\section{Environment, Safety, Health, and Quality Plan for the TRU-Contaminated Arid Soils Project of the Landfill Stabilization Focus Area Program}

\section{ENVIRONMENTAL ISSUES}

\subsection{Responsibilities}

The Landfill Stabilization Focus Area (LSFA) Program and the personnel involved in LSFAsponsored projects have the joint responsibility for ensuring that operations at the Idaho National Engineering Laboratory (INEL) and offsite conform to all applicable environmental regulations. All personnel (both onsite and offsite) are expected to be guided by the Company Environmental Policy in forming plans, setting objectives, and conducting their day-to-day activities. This policy, as stated in the Company Environmental Manual, is as follows:

Lockheed Martin Idaho Technologies (LMIT) is committed to the environmental preservation and restoration of the INEL. As responsible stewards, we will conduct our activities in such a manner as to protect the physical environment by complying with applicable regulations. Because of our strong regard for environmental protection, we will manage and operate the INEL in a manner that gives priority to this protection.

All LSFA projects are required in their Technical Task Plans (TTPs) to receive approval of documentation required by the National Environmental Policy Act (NEPA). Principal investigators (PIs) must prepare an Environmental Checklist (EC) at the beginning of the project and submit the EC to LSFA or, if activities will be performed at another government facility, to the respective DOE operations office or other government agency. Copies of NEPA documentation prepared at other government facilities must be supplied to the Project Manager and included in the project file.

The LSFA Project Manager has the responsibility to submit the EC to the LMIT Environmental Protection Department (EPD). EPD assists LSFA with conforming to requirements of the National Environmental Policy Act (NEPA) and all other applicable environmental regulations. EPD has received authority from DOE-ID to be the point of contact for LMIT NEPA actions. Bruce Angle has been designated as the EPD interface for LSFA projects/actions. He is responsible for ensuring timely NEPA review and recommendation of the appropriate NEPA documentation for proposed actions as requested by LSFA. The Project Manager is responsible to ensure that the Environmental Checklist is prepared and that approval is received before the project begins.

Each PI is responsible for minimizing the generation of both hazardous and nonhazardous wastes. LSFA will assist with recycling efforts as mentioned in Section 1.3. 


\subsection{NEPA and Associated Regulations}

The National Environmental Policy Act of 1969 declared a national policy of greater environmental awareness by requiring a systematic, interdisciplinary review of any proposed Federal action. The review is designed to assess the environmental impacts of the action; propose and assess alternatives to the action, if any, and state any irreversible and irretrievable commitments of resources involved in the proposed action should it be implemented. NEPA also required consultation with and comments from any Federal, state, and local agencies with jurisdiction or interest in the proposed action, as well as providing an opportunity for public input.

Compliance with NEPA and its documentation requirements is mandatory for proposed Federal actions involving new construction or modifications to existing facilities, projects, programs, and activities. Federal actions include activities that are performed by Federal employees, take place on Federal property, and/or are Federally funded. Physical activities such as site preparation, material purchases, irreversible commitment of resources, or any other action that tends to preclude implementation of reasonable alternatives cannot proceed until DOE written approval of NEPA documentation has been received.

\subsubsection{NEPA Process}

In addition to determining the type of NEPA documentation required for the proposed action, the NEPA review process includes determining the applicability of the following:

- The Clean Air Act and State of Idaho implementing regulations that apply to any construction, modification, or operation of equipment that emits pollutants into the atmosphere

- The Resource Conservation and Recovery Act (RCRA), which applies to management of solid and hazardous wastes

- The Safe Drinking Water Act, which applies to any industrial or domestic waste water treatment or disposal action

- The Clean Water Act, which protects threatened or endangered organisms

- The American Indian Religious Freedom Act

- DOE Orders that regulate radiation exposures to personnel to as low as reasonably achievable (ALARA) levels

- Other laws and regulations (e.g., state laws) applicable to the proposed action.

The EPD and the respective LSFA Safety, Health, and Quality representatives will assist the PI with resolving any condition that arises during this review, such as applying for an air permit. The LSFA contact for Environmental, Safety, Health, and Quality (ESH\&Q) for direction to the appropriate discipline or issues is Lewis C. Rounds [(208) 526-0063]. 


\subsubsection{NEPA Sequence of Events}

The process for NEPA documentation approval within the LSFA program is summarized below. This summary discusses primarily the projects whose NEPA documentation is the responsibility of LMIT. Projects that are performed at other government facilities are the responsibility of the company performing the task, and PIs will submit ECs and obtain NEPA approval through their respective agency or DOE operations office. Copies of ECs and approved NEPA documentation shall be supplied to the Project Manager at the INEL LSFA program office within 10 working days of preparation or approval. Any problems with receiving approval should be discussed with the Project Manager and the ESH\&Q contact as soon as possible.

1. The project PI [or the project manager (PM)] prepares an EC at the beginning of the project and submits the checklist to the EPD preventative. All projects must have ECs prepared, including those involving only office work. Sample ECs may be obtained from Lewis Rounds or Bruce Angle.

2. When EPD receives the EC, an official file is established by issuing a tracking number to the project.

3. EPD performs a review of the $\mathrm{EC}$ as follows:

a. Determine if the EC meets minimum requirements (i.e., is the form the latest revision of the EC? Are all data fields addressed? Are contacts identified? Is the project description, purpose, and need clearly stated?).

b. Determine if the EC is internally consistent (i.e., does the environmental concerns section match the project description? For example, if waste disposal is part of the action described in the project description, is the solid waste question in the environmental concerns section of the checklist answered "yes"?).

c. Initiate RCRA air and water (or other environmental regulations) review and determine impacts to any environmentally sensitive areas (e.g., floodplains/ wetlands, threatened or endangered species, cultural resources) and assess impacts in the NEPA documentation.

d. Determine if the environmental concerns are adequately addressed and review the proposed action for DOE "sensitivities" (i.e., is the proposed action unusual or in an area that has required special review and consideration in the past?).

e. The EPD reviewer typically requires discussions with LSFA, the PI, and/or the PM during this phase of the NEPA process to document details of the proposed action and adequately assess potential impacts.

4. EPD makes a NEPA documentation recommendation, prepares a Categorical Exclusion (CX) if appropriate, checks the Category Evaluation Criteria in section D for accuracy, and signs the EC in Section E. 
5. PI/PM review for accuracy is obtained, the project data are recorded in the official project file, and the PI/PM is formally notified of the NEPA recommendation via the LSFA interface in EPD.

6 Upon receipt of the NEPA document package from EPD, the PI/PM concurs with or advises EPD that factual errors have been made and ensures correction.

NOTE: If EPD determines at this point that the proposed action is included in a previously approved NEPA document, no further NEPA review or documentation will be required.

7. If applicable, the Project Manager transmits the EPD-approved NEPA package to the appropriate DOE-ID Division Director for entry into the DOE-ID NEPA documentation review process, and provides a copy of the transmittal correspondence to EPD. The CX/EC package then requires review and approval by the DOE-ID approval chain, which requires approximately 20 to 60 working days.

8. The PI/PM ensures that the document is approved by DOE-ID before proceeding with the action, ensures compliance with any conditions as stated in the NEPA document package, and provides information on new proposed actions and update information on ongoing actions to EPD.

\subsection{Waste Minimization and Pollution Prevention}

The mission of the LSFA program is to assist in environmental remediation, primarily through testing and evaluation of advanced technologies for waste characterization, retrieval, treatment, and containment. Little, if any, new hazardous waste is generated as a function of testing and demonstrating remediation technologies. At this time, no process has been identified in this (or out-year) demonstration and test programs that would generate new hazardous, radioactive, mixed, or land disposal restriction (LDR) waste.

The LSFA program is represented in the Environmental Research and Application's (ER\&A) 1994 Waste Minimization Plan, Subsection 2.10, "Waste Technology Development." Process Waste Assessments (PWAs), required by the plan for tracking waste minimization efforts, are not required for non-routine activities, and are not required for municipal waste, sanitary waste, or office trash. It is expected that some construction debris, such as broken glass, wood scraps, packaging materials, cement, and rubble, will be left at the Cold Test Pit (CTP) when the tests are completed. At LSFA's request, the Central Facilities Area (CFA) Landlord and program support Facilities and Maintenance (F\&M) services will remove this industrial waste and dispose of it properly at the CFA landfill. Scrap metal will be moved to CFA property control for recycling.

Simulated waste retrieved during excavation demonstrations at the Cold Test Pit will be reused to the extent it is feasible. When possible, the waste will either be reused as a source for treatment technologies funded by LSFA, reburied in the Cold Test Pit for future retrieval 
demonstrations, or stockpiled in containers at the Cold Test Pit for future pit construction. Any remaining simulated waste from retried demonstrations will be disposed of in the CFA landfill.

\subsection{INEL Field Demonstrations}

\subsubsection{Environmental Regulations}

All field testing at the INEL will be performed at the Cold Test Pit, the North Boulevard Robotics Complex, or the Box Canyon Site. Although LSFA has received approval for creation and general use of the site, each project that will field test a technology at the Cold Test Pit must undergo separate NEPA review and approval. The Cold Test Pit has received archaeological clearances, threatened and endangered (T\&E) species clearances, and approval of a Stormwater Pollution Prevention Plan (SWPPP), as required. These documents are located in the LSFA program files.

The Box Canyon Site is located on Bureau of Land Management (BLM) property. Therefore, the BLM is responsible for ensuring NEPA requirements have been met. NEPA documentation and T\&E surveys have been completed by the BLM. Archeological surveys were completed in the spring of 1994.

\subsubsection{Waste Disposal}

Procedures for disposal of solid wastes are contained in the Company Procedures Manual, Section 8.12, "Solid Sanitary Waste Segregation and Recycling Procedures for using the INEL Landfill." LSFA will have one dumpster placed at the Cold Test Pit (CTP) to receive refuse (e.g., office paper). Metal and wood will be separated and set apart for removal.

Hazardous waste generation from LSFA tests is discouraged, but controlled materials, such as hydraulic fluids, have been used in the past and their use is anticipated again in the future. The RWMC Spill Prevention Plan will be used at the CTP. The Monolithic Confinement Project has defined a Spill Plan for the Box Canyon Site. Secondary wastes from field tests are the responsibility of each technology. The LSFA Deployment Team will support the removal and ultimate disposal of secondary waste streams if requested by the PIs. 


\section{HEALTH AND SAFETY ISSUES}

\subsection{Health and Safety Plan}

LSFA projects performed at the INEL shall comply with the Occupational Safety and Health Guidance Manual for Hazardous Waste Site Activities (NIOSH/OSHA/USCG/EPA 1985); the Company Safety Manual; the Company Radiological Controls Manual; and EPA Standard Operating Safety Guides (EPA 1984). Projects performed at the INEL are covered by the Health and Safety Plan as defined in the Company Safety Manual, Section 1. Projects performed at nonINEL facilities will be responsible for following an acceptable health and safety plan for the location where the work is performed. Vendors who will be working at the INEL are required to produce safety plans for the work they will be performing. Approval of both the PI and the LSFA safety engineer are required before the vendor arrives at the INEL.

All technology development projects sponsored by LSFA shall use the following checklist to identify Health and Safety compliance issues (Table 1). If any item on this check list is a "yes," then the performer may be required to generate additional Detailed Operating Procedures (DOPs). This will be on a case-by-case basis to meet the guidance and requirements as directed by LSFA management for the specific identified issues. The DOP will be attached as an "Addendum" to the ER Health and Safety Plan (EG\&G 1991).

Table 1. Health and Safety Compliance Checklist.

\begin{tabular}{|l|l|l|}
\hline YES & NO & \multicolumn{1}{|c|}{ Health and Safety Compliance Checklist } \\
\hline & $\begin{array}{l}\text { Are there any specialized training requirements involving radioactive or } \\
\text { hazardous material that were not called out in your Demonstration Test Plan? }\end{array}$ \\
\hline $\begin{array}{l}\text { Do any of the activities of your demonstration require the use of any } \\
\text { hazardous material or involve the performance of hazardous activities requiring } \\
\text { mandatory use of specialized protective procedures? For example, fueling up a } \\
\text { portable generator is a "no," but the use of a controlled radioactive source is a } \\
\text { "yes." }\end{array}$ \\
\hline $\begin{array}{l}\text { Do any of the activities of your demonstration require the mandatory use of } \\
\text { specialized protective clothing or equipment beyond hard hats, safety shoes, } \\
\text { safety glasses, or ear plugs? For example, projects requiring the use of } \\
\text { respirators or anti-C's for personal protection would be a "yes." }\end{array}$ \\
\hline $\begin{array}{l}\text { Do any of the activities of your demonstration require an exclusion zone } \\
\text { because of excessive hazards, especially contamination? For example a safety } \\
\text { rope around a relatively shallow excavation would be a "no," but a radioactive } \\
\text { or hazardous exclusion barrier would be a "yes." However, a simulated } \\
\text { exclusion zone that is for the purpose of simulating reality during a "cold" } \\
\text { demonstration would be a "no." }\end{array}$ \\
\hline $\begin{array}{l}\text { Do any of the activities of your demonstration require a environmental } \\
\text { remediation or decontamination activity to remove radioactive or hazardous } \\
\text { contamination that was a result of your demonstration? }\end{array}$ \\
\hline
\end{tabular}


Table 1. (continued).

\begin{tabular}{|c|c|l|}
\hline YES & NO & \multicolumn{1}{|c|}{ Health and Safety Compliance Checklist } \\
\hline & $\begin{array}{l}\text { Do any of the activities of your demonstration require specialized } \\
\text { environmental monitoring for hazardous or radioactive contamination, or for } \\
\text { excessive hazards of fire, explosion, high heat, confined space, or high noise? } \\
\text { Will any activities be performed in an area defined as a "confined space?" }\end{array}$ \\
\hline & $\begin{array}{l}\text { Do any of the activities of your demonstration require specialized emergency } \\
\text { or containment equipment for fire, explosion, or contamination release } \\
\text { (hazardous or radioactive?) For example, fire extinguisher presence would be a } \\
\text { "no," but a stand-by fire engine or the required presence of Health Physicists } \\
\text { (HPs) with a hazardous/radioactive spill control kit would be a "yes." }\end{array}$ \\
\hline
\end{tabular}

\subsection{Hazard Communications}

Hazard Communication requirements are a result of Occupational Safety and Health Administration (OSHA) regulations regarding the use of hazardous chemicals. Issues that must be addressed include availability of material safety data sheets (MSDSs), a hazardous agent inventory, proper labeling, and appropriate training for personnel.

At the Cold Test Pit, all MSDSs will be located in the administration trailer. All PIs performing tests at the Cold Test Pit shall ensure that copies of the MSDSs of any chemicals they will be using are included in the MSDS binder. Copies of MSDSs for chemicals used at the Box Canyon Site shall be located in an easily accessible location to be determined by project members.

All chemicals to be used at the INEL and the amounts to be used shall be listed and provided to the ESH\&Q representative, who will ensure compliance with the Superfund Amendments and Reauthorization Act of 1986 (SARA) reporting regulations. Proper labeling and training for use of the chemical will be the responsibility of the PI.

All other projects shall follow the existing procedures of the facilities in which work is performed.

\subsection{Job Hazard Analyses}

A job hazard analysis is required for each project performed at the INEL. The analysis entails a review of the chemical, biological, and physical hazards of the operation as well as the Industrial Hygienist's (IH's) and Safety Engineer's evaluations or risk assessments of the hazards. Based on this analysis, the following issues may need to be addressed by the PI and the IH or Safety Engineer:

- Confined Spaces-A certified IH or Safety Engineer will classify, inspect, and review all potential confined spaces. 
- Hearing Conservation-Noise levels that exceed 85 decibels for $8 \mathrm{hr} /$ day duration, as measured with a sound Level meter conforming to ANSI specification 51.4 (1971) Type 52A, and set to use the A-weighted network with slow meter response. Work will be restricted to $1 \mathrm{hr}$ per day if the noise level reaches 100 decibels. All test operations will shut down if the noise level should reach 115 decibels.

- Carcinogen Control-Will be implemented if DOE-specified carcinogens must be used by a project. The LSFA IH will monitor the use of any carcinogens.

- Industrial Hygiene Monitoring-The LSFA IH will monitor the presence of chemicals and other hazardous agents at the site, if required. An assessment regarding the frequency and type of monitoring will be addressed in the job hazard analysis.

- General working conditions.

- Construction safety.

- Forklift operation.

- Gantry crane operation.

- Personnel protective equipment (PPE).

- High-pressure system training.

- Emergency procedures.

- Trenching.

- $\quad$ Operation of earth-moving equipment.

\subsection{Hazard Classifications}

Hazard classification evaluations are to be performed for all LSFA-sponsored projects before they go to the field for demonstration. Hazard classification evaluations are the responsibility of the PIs. Requirements are defined in the Company Safety Manual and a checklist can be obtained from the LSFA ESH\&Q representative.

\subsection{Training}

LSFA projects performed at the INEL shall comply with the minimum training requirements as outlined in Training Requirements and Responsibilities for the Buried Waste Integrated Demonstration at the Radioactive Waste Complex (EG\&G 1992a). 


\subsection{Safety Reviews and Checks}

The LSFA safety engineer shall conduct a safety walkdown of the CTP area weekly when field demonstrations are being performed. Safety discrepancies and concerns shall he reported to the LSFA Deployment PM. Corrections will be funded and completed by LSFA or by the demonstration PI, depending on the nature of the identified problem. Self-assessment by LSFA shall use Table 2 for monitoring.

Table 2. LSFA Field Test Monitoring Checklist.

\begin{tabular}{|c|c|c|}
\hline \multicolumn{3}{|c|}{$\begin{array}{l}\text { LSFA FIELD TEST MONTTORING CHECKLIST } \\
\text { Date completed } \\
\text { Completed by } \\
\text { Projects Monitored }\end{array}$} \\
\hline \multirow[t]{4}{*}{ YES } & NO & Generators \\
\hline & & Are the generator daily logs being kept up? \\
\hline & & Are the operating hours being tracked? \\
\hline & & Is the fuel properly stored? \\
\hline \multirow[t]{4}{*}{ YES } & NO & Daily Logbooks \\
\hline & & Are the logbooks kept in a convenient and ready-to-use place? \\
\hline & & $\begin{array}{l}\text { Are the logbooks kept in a neat manner and are changes being logged } \\
\text { properly? }\end{array}$ \\
\hline & & Are copies being transferred to LSFA at the end of each day? \\
\hline \multirow[t]{5}{*}{ YES } & NO & General Area Conditions \\
\hline & & Are housekeeping items being maintained in a reasonable manner? \\
\hline & & Are there any safety concerns/conditions/problems noted? \\
\hline & & Are there any "busy" areas, with people or equipment? \\
\hline & & Are there safety equipment in the local area? \\
\hline
\end{tabular}


Table 2. (continued).

\begin{tabular}{|c|c|c|}
\hline YES & NO & Equipment Conditions: \\
\hline & & Are the operating equipment being monitored? \\
\hline & & Are there any unusual noises? \\
\hline & & Are there any conditions, such as "jerry rigging," that need better attention? \\
\hline & & Are repairs being documented and the spare parts being replaced? \\
\hline \multirow[t]{4}{*}{ YES } & NO & Test Plans/Procedures/operating instructions: \\
\hline & & Are the procedures being followed? \\
\hline & & Are changes being controlled in a proper manner? \\
\hline & & Are the procedures located in a useable place? \\
\hline \multirow[t]{8}{*}{ YES } & NO & Documentation/data: \\
\hline & & Are the manufacturers' manuals available? \\
\hline & & Is there acceptable storage for manuals, data, information documents? \\
\hline & & Are data files being "backed up" or put in dual storage? \\
\hline & & Are problems/adverse conditions being documented? \\
\hline & & Are equipment repairs/problems being documented? \\
\hline & & Are there any unexpected personnel needs and are they being documented? \\
\hline & & $\begin{array}{l}\text { Are any conflicts in what equipment or who should be performing at } \\
\text { different times being documented? }\end{array}$ \\
\hline \multirow[t]{2}{*}{ YES } & NO & Construction: \\
\hline & & $\begin{array}{l}\text { Any overhead work, safety belts, hard hats, safety glasses, shoes, and gloves } \\
\text { need to be worn and area below roped off. }\end{array}$ \\
\hline \multirow[t]{2}{*}{ YES } & NO & Excavation: \\
\hline & & Sloping criteria observed or roped off with safety rope. \\
\hline \multicolumn{3}{|c|}{ Comments: } \\
\hline
\end{tabular}


LSFA and subcontractor personnel are responsible for complying with the applicable sections of the Company Safety Manual, the Company Industrial Hygiene Manual, the RWMC Operational Safety Requirements Safety Analysis Report (EG\&G 1988), the Company Conduct of Operations Manual, and the Environmental Restoration Program Preparation of Task-Specific Health and Safety Plans (EG\&G 1992b). If required, safety-related training is available from centralized safety training at the Central Facilities Area (CFA).

\subsection{Safe Work Permits}

All work performed at the INEL must be reviewed and approved by a Facility Health and Safety Representative, and documented in Safe Work Permits as determined by the safety representative. All work will be performed in compliance with all of the health and safety requirements for the LSFA project as identified in the LSFA Program Management Plan, and as required by this ESH\&Q plan for LSFA. 


\section{QUALITY ISSUES}

This section provides information to assist PIs in providing quality projects and quality data for the LSFA program. The sub-elements of this section are Quality Assurance Program (QAP), Data Quality Objectives (DQOs), and Comprehensive Environmental Response, Compensation, and Liability Act (CERCLA).

\subsection{Quality Program}

DOE Order 5700.6C, DOE-ID Order 5700.6E, and the Company Quality Manual require that all projects are performed using an issued and established quality program. The basis for DOE Order 5700.6C, DOE-ID Order 5700.6E, and the Company Quality Manual is the American Society of Mechanical Engineers, Quality Assurance Program Requirements for Nuclear Facilities, ASME/ANSI NQA-1. NQA-1 is divided into two sections, basic requirements and supplemental requirements. In the basic requirements section, the elements that make up a good quality program for any program/project are defined. The supplemental section is used primarily for nuclear facilities or nuclear reactors. The basis requirements in NQA-1 are approximately the same as those found in the Code of Federal Regulations 10 CFR 50 and the American National Standards Institute (ANSI) 45208 , both of which address quality programs. For LSFA, DOE has chosen NQA-1 for the basic quality assurance program.

The purpose of a QAP is to identify how the project will meet its objectives in areas such as design, procurement, fabrication, testing, verification of processes, and documentation of all the above. In other words, "did the project get what it paid for and in the form required?" All DOEsponsored projects must be covered by a QAP.

Projects funded by LSFA have the option of writing a Quality Program Plan (QPP) for their specific project if they deem necessary. This should only be done if the project needs to deviate from the QAP. Project personnel should remember that each element of the QAP should be applied using a graded approach. Elements that apply should be implemented with the rigor that is appropriate for the project needs, and what is required to meet the project objectives.

To assist the project members in determining what elements of the QAP should be reviewed and understood, the following descriptions of the elements of the QAP are given below.

QP-1 Organization-The assignment of responsibilities, such as who is responsible for verification that quality has been achieved.

QP-2 Quality Program-What level of quality is required and how will it be accomplished. This is what drives a QPP.

QP-3 Design Control-How designs are defined, controlled, and verified.

QP-4 Procurement Document Control-What procurement documents are required, what information is required on those documents, and how changes are implemented. 
QP-5 Instructions, Procedures, and Drawings-Do operating instructions, procedures and drawings receive the right reviews and do they contain the necessary quantitative or qualitative acceptance criteria?

QP-6 Document Control-Documents that specify quality requirements or prescribe activities affecting quality shall be prepared, issued, and changed in a controlled manner.

QP-7 Control of Purchased Items and Services-The quality of purchased materials, equipment, and services shall be controlled to ensure conformance to procurement document requirements.

QP-8 Identification and Control of Items-To ensure that only correct and accepted items are used or installed.

QP-9 Control of Processes-This refers to special processes that control or verify quality, such as welding, brazing, heat treating, and nondestructive examinations.

QP-10 Inspection-Inspections required to verify conformance of items and activities to specified requirements shall be performed by personnel independent from those who performed or directly supervised the items or activity being inspected. This also includes inspection plans when needed.

QP-11 Test Control-Tests required to verify conformance of an item or computer program to specified requirements and to demonstrate that items will perform satisfactorily in service shall be planned and executed.

QP-12 Control of Measuring and Test Equipment-Measurement standards and measurement and test equipment (M\&TE) used in fulfilling contractual requirements and for activities affecting quality shall be controlled and calibrated at specified intervals and adjusted to maintain required accuracy.

QP-13 Handling, Storage, and Shipping-Measures shall be established to control the handling, packaging, cleaning, preservation, storage, transporting, and shipping of material and equipment to prevent damage, loss, or deterioration.

QP-14 Inspection, Test, and Operating Status-The status of items and operating facilities shall be identified and controlled to ensure that items that have not passed required inspections and tests are not inadvertently installed, used, or operated.

QP-15 Control of Nonconforming Items-Items that do not conform to requirements shall be controlled to prevent inadvertent use or installation.

QP-16 Corrective Action-The identification, cause, and corrective actions to prevent recurrence shall be determined and documented for significant conditions adverse to quality. 
QP-17 Quality Records-Records shall be specified, prepared, reviewed, approved, and maintained to accurately reflect completed work and to furnish objective evidence of quality.

QP-18 Quality Audits-A system of planned and scheduled quality audits conducted to verify compliance with all aspects of the Company Quality Manual. These audits will be conducted internally by the LSFA Deployment QA support member.

QP-19 Readiness Review-Prior to performance, the status or prerequisites of the specified functions shall be validated by an independent review.

QP-20 Quality Improvement-Process established and implemented to detect and prevent quality problems and to ensure quality improvement.

QP-21 Computer Software Configuration Management-To establish the policy, requirements, and responsibilities for the control of computer software purchased for direct use, purchased and modified, or developed by LMIT personnel.

Using a graded approach, the QAP should not be a cost and schedule problem, but should help ensure that project costs and schedule are met along with providing a quality product that meets the customers expectations and requirements. If there are any questions, contact the LSFA Quality Engineer, Lewis Rounds [(208) 526-0063] or another qualified Quality Professional.

\subsection{Data Quality Objectives}

DQOs are both qualitative and quantitative statements that specify the targeted quality required of data gathered during testing. Indicators of DQOs include precision, accuracy, representativeness, completeness, and comparability. The DQOs should be identified as early as possible. DQOs are an important part of project planning, procedure writing, and test plan preparation. In addition, established DQOs define the importance of the various sets of data, enabling decisions to be made on equipment, materials, operating procedures, cost, and schedules in a way that will best support the project.

There are several processes that can be used to determine DQOs for a project. EPA report QAMS 005/80 defines one method, but is directed primarily toward sampling data. A DQO process is identified in EGG-WTD-9800, Test Plan Guidance.

The purpose of defining DQOs is to identify what data are critical, important, desirable, or not of much importance to the project. The number of categories and what data that fit each category are dependent on the PI. Knowing how important each set of data is, both before and during testing, the PI can then apply the DQO indicators to each. With this information at hand, any decisions on necessary or suggested changes both before and during testing can be made with positive (or minimal) effects on the final data collected during testing. DQOs are also helpful if the project budget increases or decreases. DQOs help identify areas where increased funding will be most useful or cuts can be made with minimal effects. 
A well-defined set of DQOs is an asset to a project and should be established very early. If you need help defining DQOs or have any questions, contact the LSFA Quality Engineer, Lewis Rounds [(208) 526-0063] or another qualified Quality Professional.

\subsection{CERCLA Evaluation Criteria}

LSFA has included the CERCLA criteria for evaluating the buried waste remediation technologies it is funding. These criteria are used because end products of LSFA are intended for use by the national environmental restoration/waste management (ER/WM) community, who will be required to comply with CERCLA. The nine CERCLA criteria to be considered are as follows:

1. Overall Protection of Human Health and the Environment-This category is for analyzing whether the technology can adequately protect human health and the environment, in both the short-and long-term, from unacceptable risks.

2. Compliance with Applicable or Relevant and Appropriate Requirements (ARARs)-This category is for analyzing whether the technology can comply with applicable or relevant and appropriate requirements under Federal environmental laws and state environmental or facility siting laws, or can provide grounds for invoking a waiver.

3. Long-Term Effectiveness and Permanence-This category is for evaluating the longterm effectiveness and permanence the technology affords, along with the degree of certainty that the technology will prove successful. Included should be an analysis of the magnitude of residual risk and the reliability and adequacy of controls.

4. Reduction of Toxicity, Mobility, and Volume Through Treatment-This category is for determining the degree to which the technology employs recycling methods or treatments that reduce the toxicity, mobility, or volume of a waste, including how treatment is used to address the principal threats posed by the site.

5. Short-Term Effectiveness-This category is for evaluating the short-term impacts of technologies, including protection of the community and workers during remedial actions, impacts on the environment, and time until remedial action objectives are achieved.

6. Implementability-This category is for identifying the ease or difficulty of implementing the technology.

7. Cost-This category is for identifying capital costs (both direct and indirect), annual operation and maintenance (O\&M) costs, and net present value of capital and O\&M costs. 
8. State Acceptance-This category is for assessing State concerns and may not be completed until comments on the Remedial Investigation/Feasibility Study (RI/FS) process are received. However, the category should be discussed to the extent possible.

9. Community Acceptance-This category includes determining which components of the technology that persons in the community support, have reservations about, or oppose.

Additional information for each criterion can be found in EPA-540/G-89/004, Chapter 6, or Federal Register/Vol. 55, No. 46/ Thursday, March 8, 1990/ Rules and Regulations pages 8849 and 8850 .

\subsection{Performance and System Audits}

Performance audits are conducted to quantitatively evaluate the outputs of a measurements system. System audits are conducted to qualitatively evaluate the operational details of a quality assurance (QA) program. These audits will be conducted internally by the LSFA Deployment QA support member.

A system audit to verify that the instrument(s) are operating within expected parameters will be done before and after the INEL demonstration by the respective operations personnel. This information will be documented in the Pl's logbook. 


\section{REFERENCES}

American Society of Mechanical Engineers (ASME), Quality Assurance Program Requirements for Nuclear Facilities, ASME/ANSI NQA-l.

EG\&G, 1988, RWMC Operational Safety Requirements Safety Analysis Report.

EG\&G, 1991, Health and Safety Plan for the Buried Waste Program.

EG\&G, 1992a, Training Requirements and Responsibilities for the Buried Waste Integrated Demonstration at the Radioactive Waste Management Complex.

EG\&G, 1992b, Environmental Restoration Program Model for Preparation of Task-Specific Health and Safety Plans.

Company Environmental Manual.

Company Procedures Manual.

Company Industrial Hygiene Manual.

Company Conduct of Operations Manual.

Company Safety Manual.

Company Radiological Controls Manual.

Company Quality Manual.

Environmental Protection Agency (EPA), 1984, Standard Operating Safety Guides.

ER\&A, 1994, Waste Minimization Plan.

NIOSH/OSHA/USCG/EPA, 1985, Occupational Safety and Health Guidance Manual for Hazardous Waste Site Activities. 